\title{
Duas perspectivas sobre o projeto educacional da Companhia de Jesus
}

\author{
Fábio Alves dos Santos
}

\begin{abstract}
Resumo
Pretendo, no presente artigo, discorrer acerca dos elementos apresentados em duas leituras distintas sobre o período jesuítico da educação no Brasil. A primeira delas é a que foi elaborada por Fernando de Azevedo (1976); a segunda, é a de João Adolfo Hansen (2000; 2001). O objetivo é destacar a forma como essas interpretações explicaram a ação educativa da Companhia de Jesus no Brasil. Cotejar as duas leituras sobre a atuação jesuítica no setor educacional brasileiro no período colonial, como aqui foi feito, requer considerar o local de fala em que foram produzidos os discursos, bem como a perspectiva histórica que os enquadra.
\end{abstract}

Palavras-chave: Educação Jesuítica, História da Educação Brasileira, Historiografia da Educação

\section{Two perspectives about the educational project from the Company of Jesus}

\begin{abstract}
I intend, with this article, to talk over the elements presented in two distinct readings about the Jesuit period in brazilian education. The first reading is the one elaborated by Fernando Azevedo (1976). The second reading is from João Adolfo Hansen (2000; 2001). The objective here is to make salient the way how these interpretations explained the educative action of the Company of Jesus in Brazil. To confront both readings about the Jesuit performance in the brazilian educational system in colonial era, as it was made here, it requests to consider the place where the discourses were produced, as well as the historical perspective that frame them all.
\end{abstract}

Keywords: Jesuit Education, Brazilian Education History, Historiography of Education. 


\section{Introdução}

Uma fé inabalável, como a dos primeiros apóstolos, e dispostos a todos os sacrifícios. (AZEVEDO, 1976, p. 10)

É no âmbito [da] política católica que as noções de educar, educação, civilizar e civilização devem ser definidas, evitando-se a generalização "transistórica" de sua significação e sentido. (HANSEN, 2000, p. 24)

Pretendo, no presente artigo, discorrer acerca dos elementos apresentados em duas leituras distintas sobre o período jesuítico da educação no Brasil. A primeira delas é a que foi elaborada por Fernando de Azevedo (1976); a segunda, é a de João Adolfo Hansen (2000; 2001). O objetivo é destacar a forma como essas interpretações explicaram a ação educativa da Companhia de Jesus no Brasil.

A fim de melhor atender o objetivo proposto, creio ser necessário situar os dois estudos. O de Azevedo faz parte de sua obra introdutória ao censo brasileiro de 1940, intitulada A cultura brasileira. O texto é o primeiro capítulo do terceiro tomo - A transmissão da cultura - chamado "O sentido da educação colonial".

A interpretação dada por Hansen ao fenômeno em foco será analisada a partir de dois artigos seus, ambos produzidos no âmbito das comemorações dos quinhentos anos da chegada da frota cabralina às terras (que ficaram) conhecidas pelo nome de Brasil. Um texto recebeu o título "A civilização pela palavra", o outro "Ratio studiorum e a política católica ibérica no século XVI".

Outro dado que merece destaque são os testemunhos evocados pelos autores a fim de analisar o ensino jesuítico no Brasil. Nesse sentido, Azevedo alertou para o fato de que em seu estudo não "se havia proposto vasculhar arquivos, para exumar do esquecimento velhas peças documentárias" (AZEVEDO, 1976, p. 17), consistindo seu trabalho numa síntese, as quais foram muito citadas, para o caso da Companhia de Jesus, obras de Serafim Leite, Gilberto Freyre, Moreira de Azevedo, Pedro Calmon, dentre outros, além de relatos de viajantes estrangeiros que visitaram o Brasil no século XIX, como Adolf de SaintHilaire e Max Leclerc.

Quanto a Hansen, seu discurso pautou-se fundamentalmente no Ratio Studiorum atque Institutio Societatis Jesu e em outros textos jesuíticos produzidos no calor da Contra-Reforma e "que definiam saberes a serem ensinados e condutas a serem inculcadas, e um conjunto de práticas, que permitiam a transmissão desses saberes e a incorporação de comportamentos, normas e práticas". O objetivo do autor é, na forma de uma arqueologia, reconstruir elementos da estrutura, da função e do valor da cultura escolar jesuítica no século XVI (HANSEN, 2001, p. 13).

Ditas essas coisas, passarei aos textos aludidos como referenciais para o entendimento que aqui se pretende. Primeiramente, será analisado o trabalho de Azevedo. A ordem de apresentação dos estudos devese ao fato de a obra deste autor constituir-se em marco de análise para a historiografia educacional brasileira, tendo instituído um modo de explicar o percurso da educação no país seguido de alguma forma por muitos estudos posteriores.

\section{Fernando de Azevedo e a atuação educacional da Companhia de Jesus no Brasil}

Ao iniciar seu estudo acerca dos jesuítas no Brasil, Azevedo colocou o leitor imediatamente em contato com uma de suas principais teses sobre o assunto. Assim, fica-se logo com a informação de que os jesuítas chegaram ao Brasil em 1549 para dar início a mais longa fase da história da educação brasileira. Não só a mais extensa etapa, como também "a mais importante pelo vulto da obra realizada e sobretudo pelas conseqüências que dela resultaram para a nossa cultura e civilização" (AZEVEDO, 1976, p. 09).

A partir disso, segue a descrição da atuação dos jesuítas no setor educacional em território brasileiro. Azevedo pintou um retrato dos jesuítas como indivíduos obstinados em sua missão evangelizadora, "dispostos a todos os sacrifícios" para garantir a disseminação da fé católica entre os indígenas e a manutenção da mesma nos colonizadores europeus. Segundo o 
autor em foco, "os jesuítas não estavam servindo apenas à obra da catequese, mas lançavam as bases da educação popular e, espalhando nas novas gerações a mesma fé, a mesma língua e os mesmos costumes, começavam a forjar, na unidade espiritual, a unidade política de uma nova pátria” (idem, p. 15).

No entender de Azevedo, através de seu projeto cristianizador, a Companhia de Jesus instalou no Brasil um verdadeiro sistema de ensino. Eram diversos estabelecimentos educacionais, por todo o território, com uma direção centralizada e um fim único. Tal sistema, para aquele estudioso, foi tão eficaz que se perpetuou na própria formação cultural da nação brasileira. Era um poder de tal monta que na sociedade patriarcal do Brasil Colônia constituía a única força capaz de confrontar-se com a do senhor de engenho.

Para Azevedo, a obra jesuítica é fundamental mesmo para entender as dessemelhanças existentes entre a América do Norte - protestante - e a América do Sul - católica. "As disposições de idéias e de processos de educação, na América do Sul e na do Norte", afirma ele, "provêm não só da diversidade de temperamentos dos povos que conquistaram e colonizaram essas regiões, mas da oposição entre duas concepções cristãs" (idem, p. 25). A Companhia de Jesus atuaria, assim, "em defesa da Igreja, contra a Reforma e o espírito moderno".

Daí, conclui Azevedo, o modelo educacional empregado pelos discípulos de Inácio de Loyola. O sistema de ensino estabelecido no Brasil, no entender desse autor, era pautado "no apego ao dogma e à autoridade”. A "tradição escolástica e literária, o desinteresse quase total pela ciência e a repugnância pelas atividades técnicas e artísticas tinham forçosamente de caracterizar, na Colônia, toda a educação modelada pela Metrópole que se manteve fechada e irredutível ao espírito crítico e de análise" (idem, p. 24).

Nessas características é que residia, para Azevedo, a deficiência da educação jesuítica. Se, por um lado, a Companhia de Jesus implantou um sistema fundamental para constituir uma nação brasileira através da transmissão de uma cultura comum, por outro lado, não possibilitou que o Brasil adentrasse nos trilhos da Modernidade que avançavam pelas prin- cipais nações européias e já faziam parte do gene da nação norte-americana.

\section{A leitura de João Adolfo Hansen sobre a educação jesuítica}

Para falar daquilo que chamou de "cultura escolar jesuítica", Hansen fundamentou-se primordialmente no Ratio studiorum atque Institutio Societatis Jesu, obra produzida pela Companhia de Jesus publicada no ano de 1599, e associou a atuação educacional jesuítica à "política católica” portuguesa.

Em ambos os trabalhos do autor, figuram esses dois elementos que, segundo ele, são indispensáveis para situar a ação dos discípulos de Inácio de Loyola dentro das “categorias teológico-políticas" próprias de seu tempo e assim evitar "os anacronismos decorrentes da universalização retrospectiva de categorias iluministas e liberais" (HANSEN, 2001, p. 13).

Hansen identificou o projeto da Companhia de Jesus ao tempo da Reforma e da Contra-Reforma, movimentos ocorridos no século XVI. Neste período, a Igreja Católica viu-se diante da ameaça das religiões protestantes e do questionamento de seus dogmas fundamentais. O autor em questão definiu o debate em torno da tese luterana de que só com a fé e só com a escritura seria possível alcançar a salvação da alma como o ponto nodal do modo de estruturação da ação jesuítica no campo educacional. Contra a referida tese, os padres reunidos no Concílio de Trento defenderam a tradição e a transmissão oral como as verdadeiras formas de alcançar o Reino dos Céus.

Todavia, Hansen chama a atenção para o fato de que a repercussão das teses luteranas não se limitou ao campo religioso. Politicamente, resultou na defesa do direito divino dos monarcas governarem. Os reis estariam na terra para organizar a "irremediável anarquia da humanidade decaída" (HANSEN, 2000, p. 21), uma vez que, sobre esta, pesaria a lei do pecado original. Contra essa tese, a Igreja Católica formulou o conceito de corpo místico do Estado. Por esse entendimento, "O povo todo, como um único corpo de vontades unificadas, ou seja, como um único corpo místico, aliena-se do poder e o transfere para a pes- 
soa mística do rei, que é a pessoa sagrada porque representativa da sabedoria popular" (idem, p. 25).

Segundo Hansen, a teoria do corpo místico é fundamental para, a partir da política católica, entender o processo educativo desenvolvido pela Companhia de Jesus. Esta ordem religiosa agiria no sentido de "tornar mais homem" os membros da sociedade. Esse homem seria aquele que estaria pré-disposto a uma subordinação livre, essencial para o sucesso do bem-comum. No intuito daquela formação, considera-se fundamental o desenvolvimento de três faculdades humanas: a memória, a vontade e a inteligência (idem, p. 25). Para atender aquele propósito formativo, a Igreja contra-reformada reativou a Retórica ciceroniana.

Assim, a partir dos elementos dispostos em seus artigos, o entendimento de Hansen sobre a pedagogia jesuítica é de que a retórica não constituía uma simples matéria de ensino com as outras, "mas principalmente um modo de pensar e de organizar todas as representações das matérias em todas as atividades dos cursos" (HANSEN, 2001, p. 19). Através da retórica é que se desenvolvia o súdito perfeito para o Estado português e o bom fiel para a Igreja Católica.

\section{Algumas considerações possíveis}

Cotejar as duas leituras sobre a atuação jesuítica no setor educacional brasileiro no período colonial, como aqui foi feito, requer considerar o local de fala em que foram produzidos os discursos, bem como a perspectiva histórica que os enquadra.

Dessa forma, embora o trabalho de Azevedo não constitua uma obra acadêmica nos moldes hodiernos, é preciso considerar que seu discurso guarda uma perspectiva histórica finalista. O título do capítulo que dedica longo espaço à Companhia de Jesus é bastante elucidativo. O autor tratou ali do "sentido" da educação colonial. A constituição da civilização brasileira é este "sentido". A Companhia de Jesus, no entender de Azevedo, foi a responsável por aquela constituição. Essa é uma afirmação forte quando se considera que, mesmo após sua expulsão, os jesuítas mantiveram sua herança através da perpetuação de seu modelo de ensino, tida pelo autor como livresco e elitista.
Outra é a perspectiva de Hansen. Situado num momento de forte revisão das principais teses sobre a história da educação brasileira, seus estudos constituem legítimos trabalhos acadêmicos, conforme os códigos de um campo de estudos que vem se estabelecendo, principalmente nas últimas décadas do século XX. A forma de leitura sobre os fenômenos educacionais, em textos como os de Hansen, são marcados por uma metodologia específica, como também é específica a base teórica na qual se pautou.

É preciso considerar também o pioneirismo da obra de Azevedo no intuito de construir uma história da educação no Brasil. Como já foi dito linhas acima, sua obra constitui um marco nas interpretações educacionais. Os trabalhos que se seguiram, quando não concordaram com sua abordagem, seguiram ao menos os mesmos marcos cronológicos por ele estabelecidos. Hansen, por sua vez, colocou-se no contraponto interpretativo que veio se estabelecendo nos últimos anos. É elucidativo disto a crítica feita pelo autor na terceira nota de seu artigo sobre o Ratio Studiorum e a política católica ibérica no século XVII. Aliás, em todo esse texto é explícita a crítica de Hansen às interpretações que, segundo ele, são eivadas de "anacronismos decorrentes da universalização retrospectiva de categorias iluministas e liberais" (HANSEN, 2001, p. 13). Ou seja, os elementos de crítica de que dispunha Hansen, no momento de elaboração de seus textos, não foram sequer conhecidos por Azevedo.

Faz-se necessário levar em conta, ainda, que no momento em que Azevedo redigiu sua interpretação, a Sociologia era campo incipiente, em estado de gestação. Hansen, por outro lado, edificou sua análise no aporte conceitual e metodológico da Nova História Cultural, como representação e apropriação que acabam por gerar resultados bastante diferentes do que os frutos da idéia de evolução, por exemplo.

Assim, a conclusão a que chego depois de colocar face a face as duas leituras é que são leituras distintas, porque distintas são suas perspectivas. São obras de valores próprios, seja pela gama de informações que fornecem, seja pela forma como interpretam essas informações, bem como por constituírem modelos interpretativos possíveis que marcam momentos específicos da historiografia educacional brasileira. 


\section{Referências}

AZEVEDO, Fernando. 1976. A cultura brasileira. Tomo III - A transmissão da cultura. 5 ed. São Paulo: Melhoramentos; Brasília: INL.

HANSEN, João Adolfo. 2000. A civilização pela palavra. IN: LOPES, Eliane Marta Teixeira; FA-
RIA FILHO, Luciano Mendes; VEIGA, Cynthia Greive (orgs.). 500 anos de educação no Brasil. Belo Horizonte: Autêntica. p. 19-42.

.2001. Ratio Studiorum e a política católica ibérica no séculoXVII.IN:VIDAL, Diana Gonçalves; HILSDORF, Maria Lúcia Spedo (orgs.). Brasil 500 anos: tópicos em História da Educação. São Paulo: Edusp. p. 13-41.

\section{Sobre o Autor:}

Fábio Alves dos Santos é mestre em educação pela PUC-São Paulo e professor substituto do Departamento de Educação da UFS. 
